\title{
Mechanism of Anomalous Type Electrodeposition of Fe-Ni Alloys from Sulfate Solutions
}

\author{
Hiroaki Nakano ${ }^{1}$, Masayuki Matsuno ${ }^{2}$, Satoshi Oue ${ }^{1}$, Masaaki Yano ${ }^{3}$, \\ Shigeo Kobayashi ${ }^{2}$ and Hisaaki Fukushima ${ }^{1}$ \\ ${ }^{1}$ Department of Materials Science \& Engineering, Kyushu University, Fukuoka 812-8581, Japan \\ ${ }^{2}$ Department of Industrial Chemistry, Kyushu Sangyo University, Fukuoka 813-8503, Japan \\ ${ }^{3}$ Department of Materials Science and Engineering, Kurume National College of Technology, \\ Kurume 830-8555, Japan
}

The electrodeposition of Fe-Ni alloys was performed galvanostatically in the sulfate solutions of $\mathrm{pH} 1-3$ at $40^{\circ} \mathrm{C}$ and the alloy deposition behavior was compared with that of Zn-iron-group metal alloys to investigate their codeposition mechanism. The deposition behavior of Fe-Ni alloy showed a typical feature of the anomalous codeposition, in which electrochemically less noble Fe deposits preferentially under most plating conditions. The anomalous codeposition behavior in Fe-Ni alloy deposition was evidently dependent on the pH buffer capacity of the solutions. This can be explained in terms of the preferential adsorption of $\mathrm{FeOH}$ on the deposition sites of more noble Ni due to the extremely smaller dissociation constant of $\mathrm{FeOH}^{+}$than $\mathrm{NiOH}^{+}$in the multi-step reduction process of hydrated iron-group metal ions.

(Received July 12, 2004; Accepted September 24, 2004)

Keywords: electrodeposition, iron-nickel alloy, anomalous codeposition, iron-group metal

\section{Introduction}

Electrodeposited Fe-Ni alloys have been widely used for the thin film head of magnetic recording because of their high magnetic permeability and small coercive force. ${ }^{1,2)}$ In recent years, the application of $\mathrm{Fe}-\mathrm{Ni}$ alloy films to the stress sensor of magnetostriction type has been expected. This type of stress sensors detect the tension, torque, stress and weight loaded to the subject by using the reverse magnetostrictive effect that their magnetic property changes depending on the strain applied to magnetic substances.. ${ }^{3)}$ It has been well known that the deposition behavior of Fe-Ni alloys showed a typical feature of anomalous codeposition, in which electrochemically less noble $\mathrm{Fe}$ deposits preferentially under most plating conditions. ${ }^{4-13)}$ Since the magnetic properties of Fe$\mathrm{Ni}$ alloy change greatly depending on its composition, the alloy of fixed composition should be deposited stably to keep the desired properties. Therefore, it is important to make clear the mechanism of anomalous deposition of $\mathrm{Fe}-\mathrm{Ni}$ alloys. The hydroxide suppression model ${ }^{4)}$ and the mathematical model ${ }^{5)}$ have been proposed so far to explain the anomalous codeposition of $\mathrm{Fe}$ with $\mathrm{Ni}$. The hydroxide suppression model ${ }^{4)}$ explained that noble $\mathrm{Ni}$ deposition was strongly suppressed in the presence of $\mathrm{Fe}(\mathrm{OH})_{2}$ preferentially formed and adsorbed on the cathode, while the mathematical model $^{5)}$ was based on the great difference in the dissociation constant between $\mathrm{FeOH}^{+}$and $\mathrm{NiOH}^{+}$. However, no mechanism explaining completely for the anomalous codeposition has been reported.

On the other hand, the deposition of Zn-iron-group metal alloys is one of the best-known examples of anomalous codeposition and $\mathrm{Zn}$ hydroxide suppression mechanism ${ }^{14-16)}$ is accepted widely for the anomalous deposition. In this study, the deposition of Fe-Ni alloys was performed under various plating conditions and the alloy deposition behavior was compared between $\mathrm{Fe}-\mathrm{Ni}$ and $\mathrm{Zn}-\mathrm{Ni}$ systems to investigate the mechanism of anomalous type deposition of $\mathrm{Fe}-\mathrm{Ni}$ alloys.

\section{Experimental}

Electrolytic solutions for $\mathrm{Fe}-\mathrm{Ni}$ alloy deposition were prepared by dissolving the reagent grade $\mathrm{FeSO}_{4} \cdot 7 \mathrm{H}_{2} \mathrm{O}$ and $\mathrm{NiSO}_{4} \cdot 6 \mathrm{H}_{2} \mathrm{O}(1.0 \mathrm{~mol} / \mathrm{L}$ in total metal ion concentration) in water purified by distillation and ion exchange. The $\mathrm{pH}$ was adjusted with sulfuric acid to 1, 2 or 3 (standard condition: 3 ). Besides the sulfate solutions, the chloride solutions were used in some experiments. Electrolytic solutions for Zn-irongroup metal alloy deposition were also prepared by dissolving the reagent grade metal sulfate $(1.0 \mathrm{~mol} / \mathrm{L}$ in total $)$ and the $\mathrm{pH}$ was adjusted with sulfuric acid to 1 or 3 (standard condition: 3 ). The deposition was performed in un-agitated solutions under coulostatic $\left(10^{5} \mathrm{C} / \mathrm{m}^{2}\right)$ and galvanostatic conditions at $40^{\circ} \mathrm{C}$. Copper sheet and platinum sheet of $1 \times 2 \mathrm{~cm}^{2}$ were used as the cathode and the anode, respectively. An H-section cell where catholyte was separated from anolyte by sintered glass was used for performing electrolysis. A small amount of Ar gas was injected consistently during electrolysis into the cell to prevent oxidation of $\mathrm{Fe}^{2+}$. The deposited alloys were dissolved from the cathode with nitric acid. Each metal was quantitatively analyzed by ICP, and the alloy composition, the cathode current efficiency and the partial current density for each metal deposition were calculated. The cathode potentials were measured during the alloy deposition using a saturated $\mathrm{Ag} / \mathrm{AgCl}$ reference electrode $\left(0.199 \mathrm{~V}\right.$ vs $\left.\mathrm{NHE}, 25^{\circ} \mathrm{C}\right)$. In the presentation of polarization curves, the potentials were plotted with reference to NHE.

Using $\mathrm{Sb}$ microelectrode technique, ${ }^{14)}$ the $\mathrm{pH}$ in the vicinity of the cathode was evaluated during the alloy deposition. Under galvanostatic condition, the potential of Sb electrode attached to a micrometer was measured at various distance between the cathode and Sb electrode. Using the $\mathrm{pH}-$ potential calibration curve measured in advance, the $\mathrm{pH}$ profile near the cathode was determined.

To study the hydrolysis behavior of the aqua metal ions in the solutions, the $\mathrm{pH}$ titration curves were measured. The 
$0.2-0.8 \mathrm{~mL}$ of $0.01-5 \mathrm{~N} \mathrm{NaOH}$ solution was added into $0.2 \mathrm{~mol} / \mathrm{L}$ of $\mathrm{FeSO}_{4}$ or $\mathrm{NiSO}_{4}$ solution every $30 \mathrm{~min}$. The measurement was performed in the sealed type cell and $10^{-3} \mathrm{~m}^{3} / \mathrm{min}$ of Ar gas was consistently injected to prevent oxidation of $\mathrm{Fe}^{2+}$.

To confirm the mechanism of Fe-Ni alloy deposition, pulse plating was also performed in the sulfate solution containing $0.5 \mathrm{~mol} / \mathrm{L}$ of $\mathrm{Fe}^{2+}$ and $\mathrm{Ni}^{2+}$. The plating was kept during the on-time period of the pulse current $\left(T_{\mathrm{on}}\right)$ and was interrupted during the subsequent off-time period $\left(T_{\text {off }}\right)$. The duty cycle given by $T_{\text {on }} /\left(T_{\text {on }}+T_{\text {off }}\right)$ was fixed at $0.01,0.1$ and 1 . The peak current density was changed from 10 to $10^{4} \mathrm{~A} / \mathrm{m}^{2}$.

\section{Results and Discussion}

\subsection{Electrodeposition behavior of $\mathrm{Fe}-\mathrm{Ni}$ and $\mathrm{Zn}$-iron group metal alloys}

Figure 1 shows the relationship between the content of $\mathrm{Ni}$, which is more noble than other constituent in the deposited $\mathrm{Fe}-\mathrm{Ni}$ and $\mathrm{Zn}$-iron group metal systems, and the composition of the solutions. The CRL in the figure expresses the composition reference line which shows when the masspercentage composition of the alloy just equals the metalpercentage of the solution. In the case in which Ni content of the alloys is higher than the CRL, alloy deposition of normal type occurs, indicating the preferential deposition of more noble Ni. As shown in Fig. 1, on the contrary, Ni content of the alloys was lower than the CRL in the whole composition range of the solutions. This indicates that anomalous codeposition was proceeding during the deposition of both Fe-Ni and Zn-iron-group metal alloys. The cathode current efficiency for Fe-Ni and Zn-iron-group metal alloy deposition shown in Fig. 1 was from 80 to $90 \%$.

Figure 2 shows the current density-dependence of $\mathrm{Ni}$ content of $\mathrm{Fe}-\mathrm{Ni}$ and $\mathrm{Zn}-\mathrm{Ni}$ alloys deposited from the sulfate solutions of various pH's. Ni content of the alloys was higher than the CRL at small current densities. With increasing the current density, $\mathrm{Ni}$ content markedly decreased to the alloy composition region below the CRL. Further increase in the current density resulted in the gradual increase in $\mathrm{Ni}$ content toward CRL. The curves of $\mathrm{Ni}$ content thus showed a

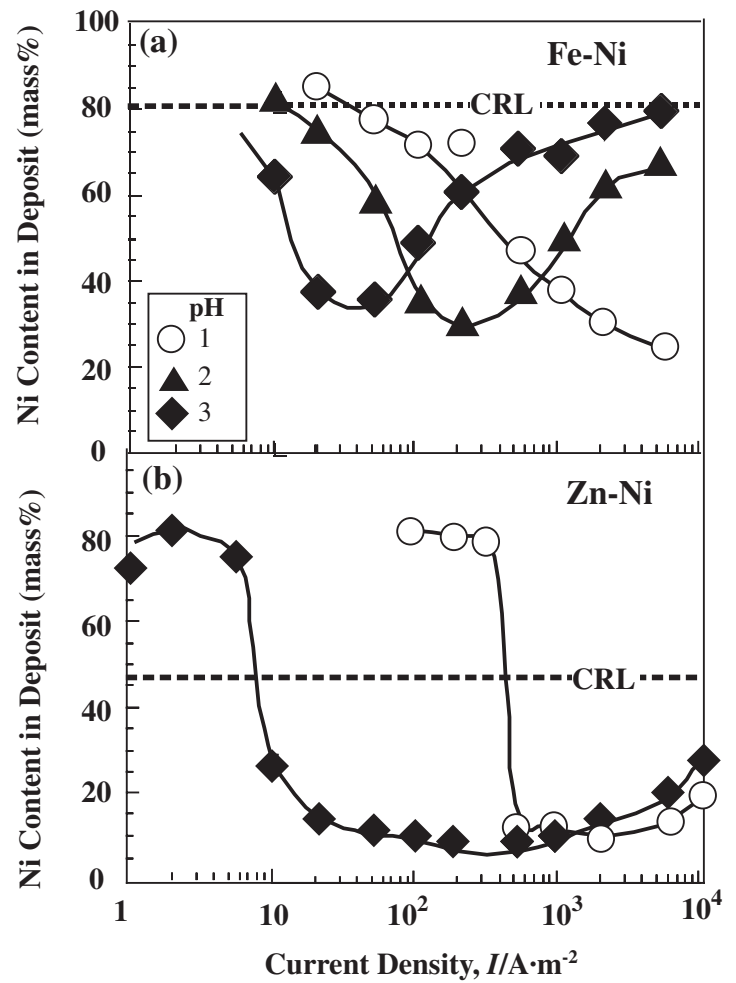

Fig. 2 Effect of current density on the composition of Fe-Ni alloy (a) and Zn-iron group metal alloy (b) electrodeposited from sulfate solutions of different pH. (a) $\mathrm{Fe}^{2+} 0.2 \mathrm{~mol} \cdot \mathrm{L}^{-1}, \mathrm{Ni}^{2+} 0.8 \mathrm{~mol} \cdot \mathrm{L}^{-1}$, (b) $\mathrm{Zn}^{2+} 0.5$ $\mathrm{mol} \cdot \mathrm{L}^{-1}, \mathrm{Ni}^{2+} 0.5 \mathrm{~mol} \cdot \mathrm{L}^{-1}$.

common feature that the normal codeposition at small current densities, the transition of the alloy deposition behavior to the anomalous type with increasing the current density and the gradual increase in $\mathrm{Ni}$ content toward the CRL at large current densities occurred.

The current density at which the deposition behavior of the alloys changes from a normal to an anomalous type is called the transition current density. ${ }^{15)}$ Figure 2 showed that $\mathrm{Ni}$ content curves were shifted to larger current density region as the $\mathrm{pH}$ of the solution lowered. This indicates that the transition current density for $\mathrm{Fe}-\mathrm{Ni}$ and $\mathrm{Zn}-\mathrm{Ni}$ alloy deposi-

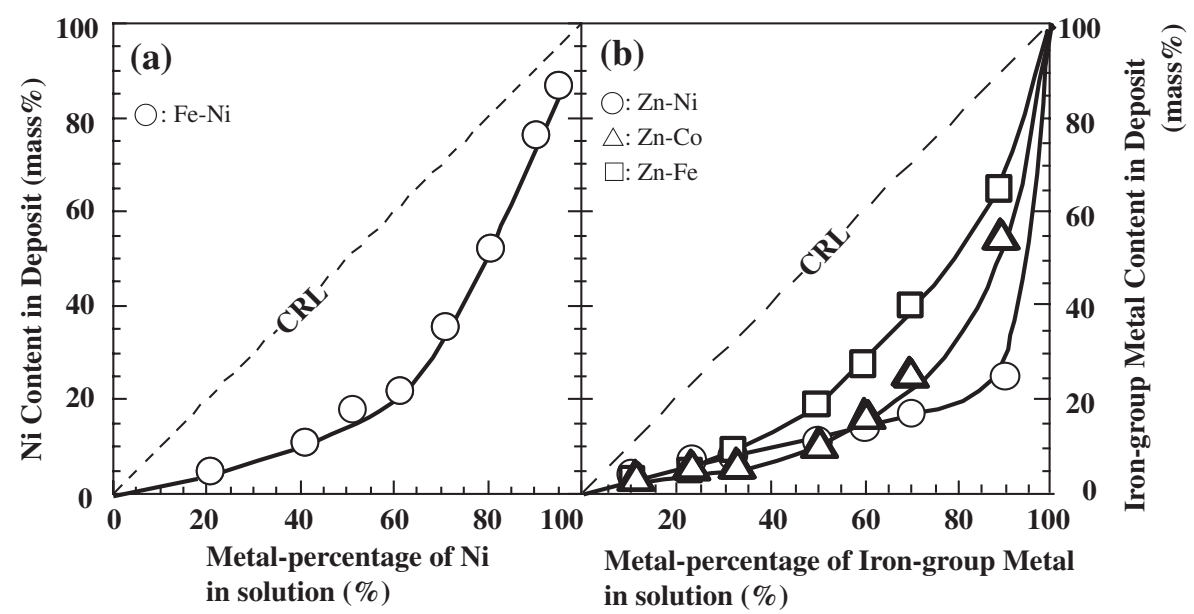

Fig. 1 Effect of solution composition on the alloy composition of Fe-Ni alloys (a) and Zn-iron group metal alloys (b) electrodeposited from sulfate solutions at $1000 \mathrm{~A} \cdot \mathrm{m}^{-2}$. Metal-percentage of $\mathrm{Ni}=[$ mass $\mathrm{Ni} /$ total mass $(\mathrm{Fe}+\mathrm{Ni})] 100$. 


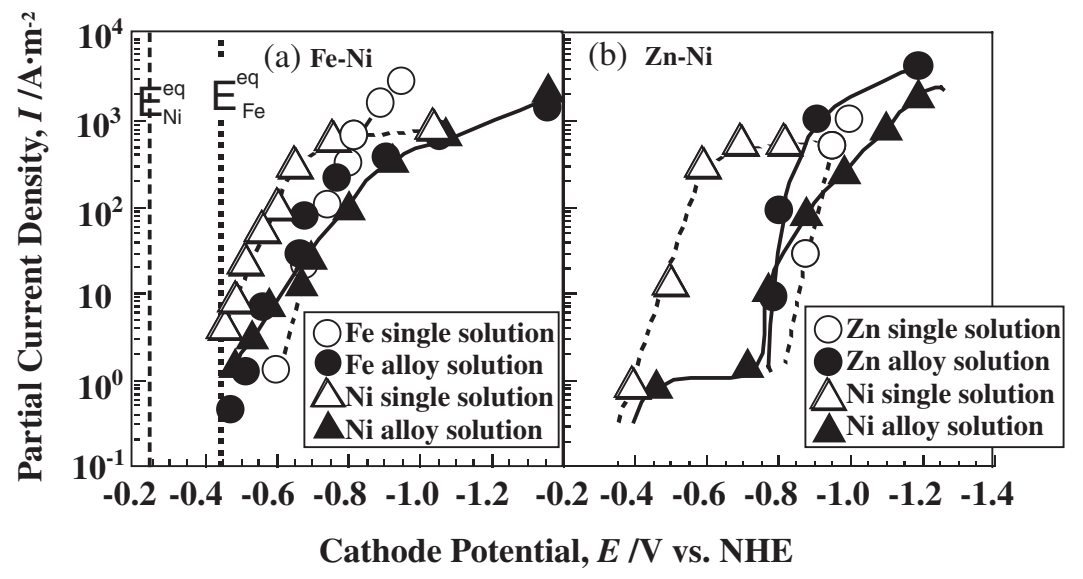

Fig. 3 Partial polarization curves for $\mathrm{Fe}, \mathrm{Ni}$ and $\mathrm{Zn}$ deposition from the solution contaning each metal sulfate alone and from the alloy solution containing both metal sulfates. (a) Fe-Ni, (b) Zn-Ni.

tion was increased and therefore the alloy deposition of a normal type proceeded in a larger range of current density when the acidity of the solutions was increased.

Figure 3 shows the partial polarization curves for $\mathrm{Fe}, \mathrm{Ni}$ and $\mathrm{Zn}$ deposition from the solution containing each metal sulfate alone (below simply referred to as metal single solution) and also from the alloy plating solution containing both metal sulfates. As shown in Fig. 3(a), the partial polarization curve for $\mathrm{Fe}$ deposition in $\mathrm{Fe}-\mathrm{Ni}$ alloy plating solution was almost identical to that in Fe single solution. On the contrary, the polarization curve for $\mathrm{Ni}$ deposition was markedly polarized in the presence of $\mathrm{Fe}^{2+}$ in the alloy plating solution. This suggests that the anomalous deposition of $\mathrm{Fe}-\mathrm{Ni}$ alloys was not caused by the depolarization of $\mathrm{Fe}$ deposition in the alloy plating solution but caused by the suppression of Ni deposition due to the codeposition of Fe. In $\mathrm{Zn}-\mathrm{Ni}$ alloy deposition, the partial polarization curve for $\mathrm{Ni}$ deposition was markedly polarized in the presence of $\mathrm{Zn}^{2+}$ in the solution as shown in Fig. 3(b), showing the same feature as $\mathrm{Ni}-\mathrm{Fe}$ alloy deposition.

\subsection{Mechanism of the anomalous type alloy deposition proposed so far}

In the anomalous type alloy deposition of $\mathrm{Fe}-\mathrm{Ni}$ and $\mathrm{Zn}-\mathrm{Ni}$ systems, as described above, the deposition of more noble $\mathrm{Ni}$ is suppressed in the presence of less noble metal ions in the alloy plating solutions. This indicates that a certain inhibitory substance containing less noble $\mathrm{Fe}$ or $\mathrm{Zn}$ ion should be formed to decrease the deposition rate of more noble Ni. The anomalous codeposition occurred easier in the solutions of higher $\mathrm{pH}$, as shown in Fig. 2, implying that $\mathrm{H}^{+}$or $\mathrm{OH}^{-}$ion is also closely related to the formation of the inhibitor.

The mechanism of anomalous type Zn-iron group metal alloy deposition has been studied well so far. At present, the hydroxide suppression mechanism ${ }^{15,16)}$ is accepted widely. According to this mechanism, $\mathrm{Zn}(\mathrm{OH})_{2}$ was formed on the cathode due to the increase in $\mathrm{pH}$ in the cathode layer and the deposition rates of iron-group metals were suppressed greatly by the inhibitory $\mathrm{Zn}(\mathrm{OH})_{2}$ adsorbed on the cathode. In this case, the $\mathrm{pH}$ in the cathode layer does not reach the critical value for iron-group metal hydroxide precipitation because of an extremely large $\mathrm{pH}$ buffer capacity of the solution due to $\mathrm{Zn}(\mathrm{OH})_{2}$ precipitation. This mechanism can explain well the characteristic alloy deposition behavior shown in Fig. 2(b) that the transition current density was increased when the $\mathrm{pH}$ of the solution lowered. In the sulfate solutions used in this work, the dissociation of $\mathrm{HSO}_{4}{ }^{-}$to $\mathrm{SO}_{4}{ }^{2-}(\mathrm{pK}=1.99)$ is the major buffering reaction and therefore the $\mathrm{pH}$ buffer capacity of the solution increases greatly when the $\mathrm{pH}$ of the solution lowers less than 2. In the solutions having larger buffer capacity, the transition current density should be increased because the larger current density for hydrogen evolution is needed to reach the critical $\mathrm{pH}$ for $\mathrm{Zn}(\mathrm{OH})_{2}$ precipitation in the cathode layer.

On the other hand, the hydroxide suppression mechanism, in which $\mathrm{Fe}(\mathrm{OH})_{2}$ was considered to act as an inhibitor, has been also proposed in the anomalous type $\mathrm{Fe}-\mathrm{Ni}$ alloy deposition. $^{4)}$ According to this mechanism, the alloy deposition behavior shown in Fig. 2(a) also seems to be explicable in the same manner as $\mathrm{Zn}-\mathrm{Ni}$ alloy deposition. In $\mathrm{Zn}-\mathrm{Ni}$ alloy plating solutions, the solubility product ${ }^{17)}$ of $\mathrm{Zn}(\mathrm{OH})_{2}$ $\left(2.0 \times 10^{-17}\right)$ is smaller enough in than that of $\mathrm{Ni}(\mathrm{OH})_{2}$ $\left(1 \times 10^{-15}\right)$, resulting in the preferential precipitation and subsequent adsorption of inhibitory $\mathrm{Zn}(\mathrm{OH})_{2}$ on the cathode. However, in $\mathrm{Fe}-\mathrm{Ni}$ alloy plating solutions, the solubility product $^{17)}$ of $\mathrm{Fe}(\mathrm{OH})_{2}$ is $2.2 \times 10^{-15}$ which is almost identical to that of $\mathrm{Ni}(\mathrm{OH})_{2}$. The critical $\mathrm{pH}$ values calculated from these solubility constants are 7.0 and 6.8 for the precipitation of $\mathrm{Fe}(\mathrm{OH})_{2}$ and $\mathrm{Ni}(\mathrm{OH})_{2}$, respectively. Therefore, both metal hydroxides are considered to precipitate almost simultaneously when the $\mathrm{pH}$ of the cathode layer increases during the alloy deposition. Consequently, the $\mathrm{Fe}(\mathrm{OH})_{2}$ suppression mechanism seems to be invalid for Fe$\mathrm{Ni}$ alloy deposition.

Hessami and Tobias ${ }^{5)}$ proposed another mechanism of Fe$\mathrm{Ni}$ alloy deposition. They assumed that the deposition of iron-group metals proceeds with preceding formation of metal hydroxide ions as expressed by following reactions.

$$
\begin{aligned}
& \mathrm{M}^{2+}+\mathrm{OH}^{-}=\mathrm{MOH}^{+} \\
& \mathrm{MOH}^{+}+2 \mathrm{e}^{-}=\mathrm{M}+\mathrm{OH}^{-}
\end{aligned}
$$




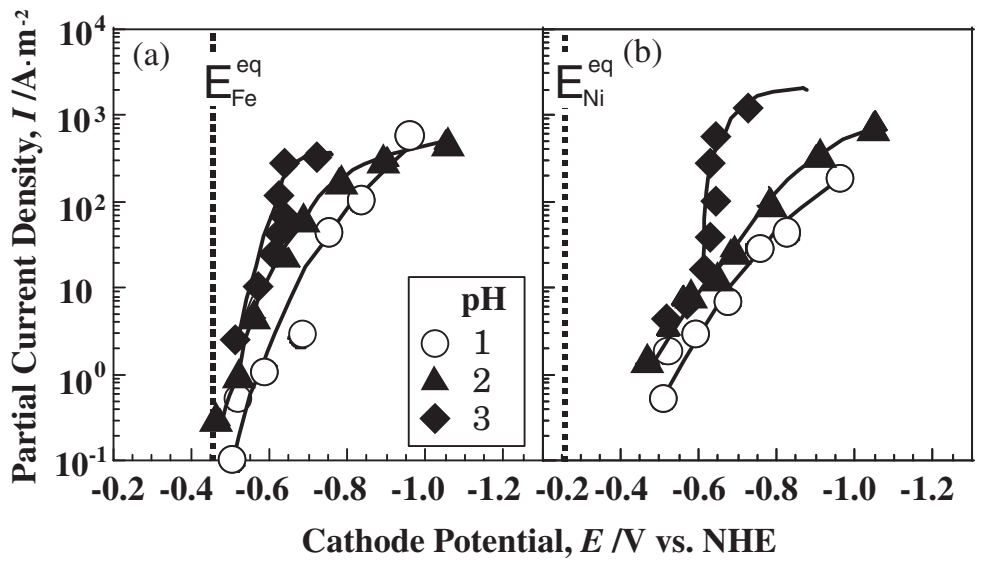

Fig. 4 Effect of $\mathrm{pH}$ in the solution on the partial polarization curves of $\mathrm{Fe}(\mathrm{a})$ and $\mathrm{Ni}$ (b) during the electrodeposition of $\mathrm{Fe}-\mathrm{Ni}$ alloys. (Fe $\mathrm{F}^{2+}$ $\left.0.2 \mathrm{~mol} \cdot \mathrm{L}^{-1}, \mathrm{Ni}^{2+} 0.8 \mathrm{~mol} \cdot \mathrm{L}^{-1}\right)$.

In above reactions, $\mathrm{M}$ expresses iron-group metals. Since the dissociation constants ${ }^{5)}$ of $\mathrm{FeOH}^{+}$and $\mathrm{NiOH}^{+}$are $5.78 \times$ $10^{-8}$ and $4.50 \times 10^{-5}$, respectively, the hydroxide ion concentration is almost thousand times smaller in $\mathrm{FeOH}^{+}$ than $\mathrm{NiOH}^{+}$in the cathode layer. As a result, $\mathrm{Fe}$ deposits preferentially under most plating conditions. However, the reason why $\mathrm{Ni}$ deposition rate was suppressed in $\mathrm{Fe}-\mathrm{Ni}$ alloy solution cannot be explained by the mechanism of Hessami and Tobias. Even if the concentration of $\mathrm{NiOH}^{+}$are markedly smaller than that of $\mathrm{FeOH}^{+}$, $\mathrm{Ni}$ deposition rate in $\mathrm{Fe}-\mathrm{Ni}$ alloy solution should be equal to that in $\mathrm{Ni}$ single solution because the concentration of $\mathrm{NiOH}^{+}$is low in both solutions and $\mathrm{FeOH}^{+}$has no effect on the Ni deposition. However, Fig. 3 showed that Ni deposition was suppressed only in the codeposition with $\mathrm{Fe}$, indicating that the mechanism proposed by Hessami and Tobias also cannot be accepted.

\subsection{Estimation of the mechanism of anomalous type Fe- $\mathrm{Ni}$ alloy deposition}

Figure 4 shows the partial polarization curves of $\mathrm{Fe}$ and $\mathrm{Ni}$ during the alloy deposition from the solutions of various $\mathrm{pH}$ 's. The figure indicated that the polarization curves of both $\mathrm{Fe}$ and $\mathrm{Ni}$ were depolarized with the increase in $\mathrm{pH}$ of the solution, suggesting that the deposition rates of both $\mathrm{Fe}$ and $\mathrm{Ni}$ were promoted when the condition accelerated the formation of such intermediate species as $\mathrm{MOH}^{+}$presented in the reactions of (1) and (2).

The increase in $\mathrm{pH}$ in the cathode layer was confirmed by directly measuring the $\mathrm{pH}$ using $\mathrm{Sb}$ microelectrode technique during Fe-Ni alloy deposition. Figure 5 shows the $\mathrm{pH}$ profiles near the cathode during the alloy deposition at the current density of 10 or $50 \mathrm{~A} / \mathrm{m}^{2}$, which is smaller or larger than the transition current density. The $\mathrm{pH}$ in the cathode layer increased slightly from the $\mathrm{pH}$ value of bulk solution at $10 \mathrm{~A} /$ $\mathrm{m}^{2}$. On the other hand, the $\mathrm{pH}$ increased considerably to reach 6.8 at $50 \mathrm{~A} / \mathrm{m}^{2}$. Then the concentration of each metal hydroxide ion formed at $\mathrm{pH} 6.8$ was calculated using the dissociation constants given by Hessami and Tobias. ${ }^{5)}$ The result showed that the concentration of the metal hydroxide ion was $0.21 \mathrm{~mol} / \mathrm{L}$ for $\mathrm{Fe}$ and $10^{-3} \mathrm{~mol} / \mathrm{L}$ for $\mathrm{Ni}$. This indicates that $\mathrm{NiOH}^{+}$is scarcely formed but $\mathrm{FeOH}^{+}$is

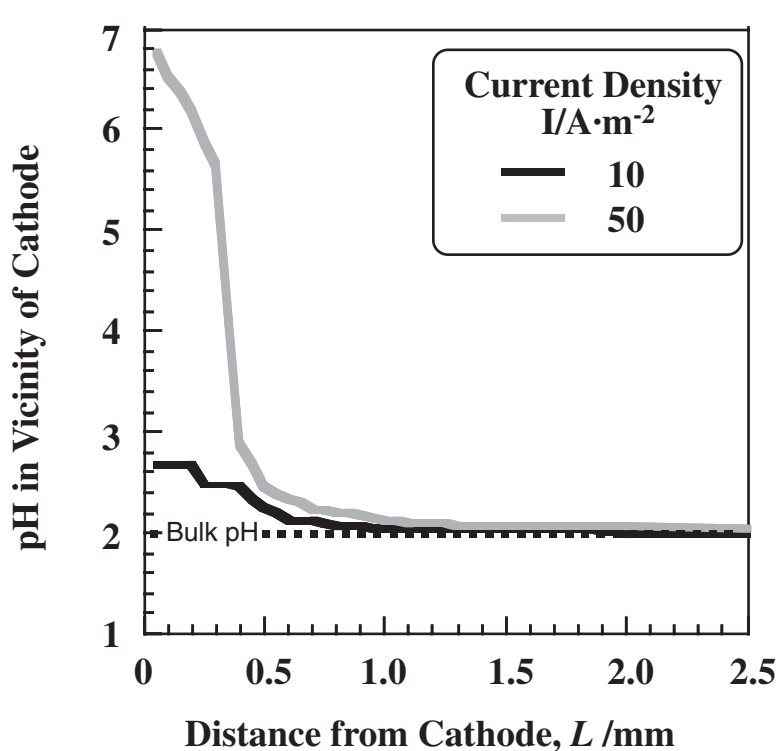

Fig. $5 \mathrm{pH}$ profiles in the vicinity of cathode during Fe-Ni alloy deposition. $\left(\mathrm{Fe}^{2+} 0.2 \mathrm{~mol} \cdot \mathrm{L}^{-1}, \mathrm{Ni}^{2+} 0.8 \mathrm{~mol} \cdot \mathrm{L}^{-1}\right)$.

formed in the cathode layer when the current density is increased to permit the anomalous codeposition.

Figure 6 shows the $\mathrm{pH}$ titration curves measured in $\mathrm{Fe}$ single or Ni single solution containing $0.2 \mathrm{~mol} / \mathrm{L}$ of its sulfate using $\mathrm{NaOH}$ solution. In the figure, the titration curves are presented in the region where the $\mathrm{pH}$ began to increase abruptly due to the hydrolysis of each metal ion. With an addition of $\mathrm{NaOH}$ solution, the titration curve of $\mathrm{Ni}$ single solution increased directly toward the critical $\mathrm{pH}$ for $\mathrm{Ni}(\mathrm{OH})_{2}$ precipitation ${ }^{17)}$ and no stagnation of $\mathrm{pH}$ due to $\mathrm{NiOH}^{+}$ formation was observed. On the other hand, the titration curve of Fe single solution showed the distinct shoulder at the $\mathrm{pH}$ range between 6.3 and 7.0 before reaching the critical $\mathrm{pH}$ for $\mathrm{Fe}(\mathrm{OH})_{2}$ precipitation. This indicated the formation of $\mathrm{FeOH}^{+}$as predicted by theoretical calculation described above. In the anomalous type Fe-Ni alloy deposition, therefore, the $\mathrm{FeOH}^{+}$must be formed in preference to $\mathrm{NiOH}^{+}$.

It is well known that the iron-group metal has the inherent 


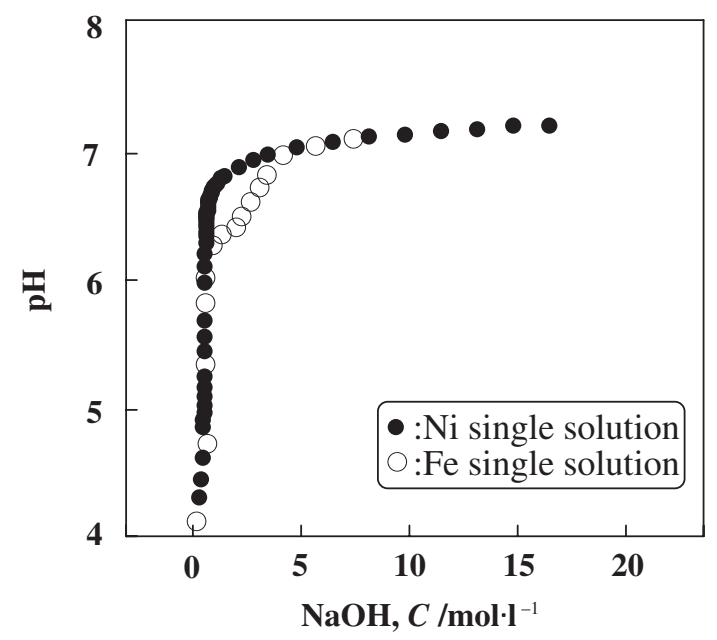

Fig. $6 \mathrm{pH}$ titration curves of the sulfate solution containing $\mathrm{Ni}^{2+}$ or $\mathrm{Fe}^{2+}$ ion. $\left(\mathrm{FeSO}_{4} 0.2 \mathrm{~mol} \cdot \mathrm{L}^{-1}, \mathrm{NiSO}_{4} 0.2 \mathrm{~mol} \cdot \mathrm{L}^{-1}\right)$.

property of not beginning to deposit at its equilibrium potential but requiring a deposition overpotential. The minimum overpotential needed for beginning iron-group metal deposition is attributed to a rate-determining step in the multi-step reduction of iron-group metal ions. A series of reactions described below has been proposed for the deposition process of iron-group metals. ${ }^{18)}$ In the reactions, $\mathrm{M}$ expresses iron-group metal and subscription "ad" for adsorbed state.

$$
\begin{aligned}
& \mathrm{M}^{2+}+\mathrm{OH}^{-}=\mathrm{MOH}^{+} \\
& \mathrm{MOH}^{+}+\mathrm{e}^{-}=\mathrm{MOH}_{\mathrm{ad}} \\
& \mathrm{MOH}_{\mathrm{ad}}+\mathrm{e}^{-}=\mathrm{M}+\mathrm{OH}^{-}
\end{aligned}
$$

According to above reactions, the deposition of iron-group metals proceeds with preceding formation of adsorbed intermediate $\mathrm{MOH}_{\mathrm{ad}}$ and the reaction (4) is rate-determining. This means that the number of adsorption sites for $\mathrm{MOH}_{\mathrm{ad}}$ is limited on the cathode. Since the concentration of $\mathrm{FeOH}^{+}$ formed in the cathode layer is, as mentioned previously, overwhelmingly higher than $\mathrm{NiOH}^{+}$, the adsorption sites for $\mathrm{NiOH}_{\mathrm{ad}}$ should be occupied by the $\mathrm{FeOH}_{\mathrm{ad}}$ in the Fe-Ni alloy deposition. Consequently, the reduction of $\mathrm{NiOH}^{+}$, shown in the reaction (4), is markedly suppressed in the alloy plating solution. Therefore, only in the case that Ni codeposits with $\mathrm{Fe}, \mathrm{Ni}$ deposition is suppressed, resulting in the anomalous codeposition.

According to the discussions presented above, it can be concluded that the inhibitor is $\mathrm{Zn}(\mathrm{OH})_{2}$ in the anomalous type $\mathrm{Zn}-\mathrm{Ni}$ alloy deposition, while in the $\mathrm{Fe}-\mathrm{Ni}$ alloy deposition, $\mathrm{FeOH}_{\mathrm{ad}}$ acts as an inhibitor which decreases the deposition rate of more noble $\mathrm{Ni}$.

\subsection{Confirmation of the mechanism proposed above}

The effects of chloride ion and pulse plating on the deposition behavior of Fe-Ni alloys were studied to confirm the mechanism proposed above. Figure 7 shows the current density-dependence of $\mathrm{Fe}-\mathrm{Ni}$ alloy composition in the chloride solutions of various pH's. The trend of the alloy deposition behavior with respect to the current density was

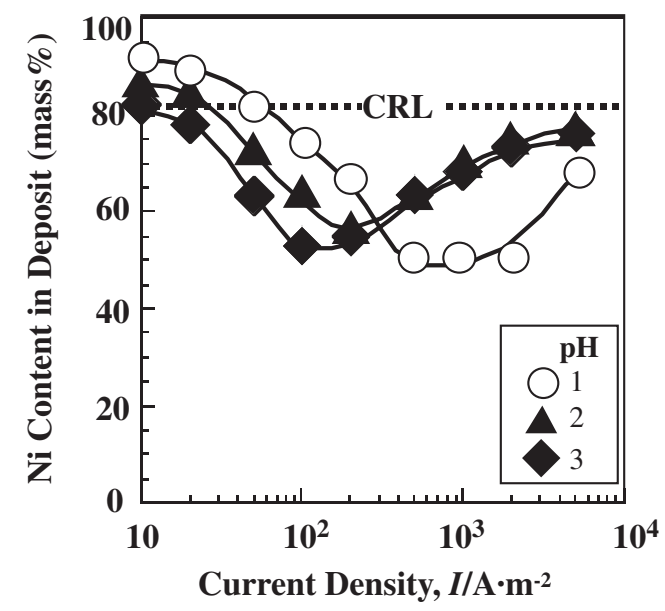

Fig. 7 Relationship between the alloy composition and the current density for $\mathrm{Fe}-\mathrm{Ni}$ alloy deposition in the chloride solutions of different $\mathrm{pH}$. $\left(\mathrm{Fe}^{2+}\right.$ $\left.0.2 \mathrm{~mol} \cdot \mathrm{L}^{-1}, \mathrm{Ni}^{2+} 0.8 \mathrm{~mol} \cdot \mathrm{L}^{-1}\right)$.

quite identical to those in the sulfate solutions shown in Fig. 2(a). However, the Ni content curves were shifted upwards in the chloride solutions when compared to the sulfate solutions, indicating the decrease of the anomaly. It was reported that the deposition of iron-group metals in the chloride solutions was performed with smaller deposition overpotential than in the sulfate solutions, because the deposition of iron-group metals in the chloride solutions proceeded with preceding formation of intermediate $\mathrm{MCl}_{\mathrm{ad}}$ which could be much more easily discharged than $\mathrm{MOH}_{\mathrm{ad}}{ }^{19)}$ Consequently, in Fe-Ni alloy deposition from the chloride solution, $\mathrm{Ni}$ deposition proceeded faster through $\mathrm{NiCl}_{\mathrm{ad}}$ whose adsorption sites were less limited, resulting in the decrease of the anomaly.

Figure 8 shows the relationship between the composition of deposited Fe-Ni alloys and the peak current density during pulse plating in the sulfate solution. The figure showed that $\mathrm{Ni}$ content curves were shifted to larger current density region as the duty cycle of the pulsed current was decreased. This indicated that the transition current density for Fe-Ni

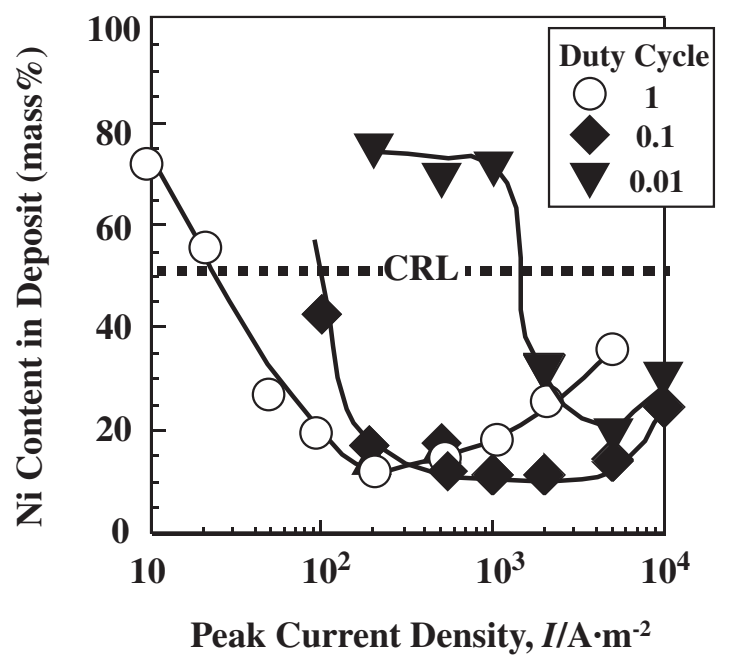

Fig. 8 Effect of duty cycle in the pulse plating on the Fe-Ni alloy composition. ( $\mathrm{Fe}^{2+} 0.5 \mathrm{~mol} \cdot \mathrm{L}^{-1}, \mathrm{Ni}^{2+} 0.5 \mathrm{~mol} \cdot \mathrm{L}^{-1}$, pulse time $100 \mathrm{~ms}$ ). 
alloy deposition was increased and therefore the current density region where the normal type alloy deposition occurred was broadened in pulse plating than in direct current plating.

In the pulse plating, the alloy is deposited during the ontime period of the pulsed current $\left(T_{\mathrm{on}}\right)$. During the subsequent off-time period $\left(T_{\text {off }}\right)$, species depleted in the cathode layer due to the electrochemical reactions are supplied from the bulk solution. Since the duty cycle of pulsed current is given by $T_{\text {on }} /\left(T_{\text {on }}+T_{\text {off }}\right)$, the increase in $\mathrm{pH}$ in the cathode layer is expected to retard when the duty cycle becomes smaller, because enough amounts of $\mathrm{H}^{+}$ions are supplied from the bulk solution during longer off-time period to prevent the increase in $\mathrm{pH}$ in the cathode layer. Therefore, the formation rate of inhibitory $\mathrm{FeOH}_{\mathrm{ad}}$ is decreased, resulting in the preferential deposition of more noble $\mathrm{Ni}$ in wider range of current density.

As discussed above in detail, the effects of chloride ion and pulse plating on the deposition behavior of $\mathrm{Fe}-\mathrm{Ni}$ alloys suggested that the degree of anomaly was decreased under the conditions which decreased the suppression effect by inhibitory $\mathrm{FeOH}_{\mathrm{ad}}$ formed on the cathode. These results demonstrate the validity of the anomalous type $\mathrm{Fe}-\mathrm{Ni}$ alloy deposition mechanism proposed in this study that $\mathrm{Ni}$ deposition is suppressed to permit the preferential deposition of less noble Fe because the adsorption sites for intermediate $\mathrm{NiOH}_{\mathrm{ad}}$ are occupied by the inhibitory $\mathrm{FeOH}_{\mathrm{ad}}$ preferentially formed and subsequently adsorbed on the cathode.

\section{Conclusion}

Deposition of $\mathrm{Fe}-\mathrm{Ni}$ alloys was performed under various plating conditions in the sulfate solutions and the deposition behavior was compared with that of Zn-iron-group metal alloys. The results obtained are described as follows.

(1) The deposition behavior of Fe-Ni alloy showed a typical feature of the anomalous codeposition, in which electrochemically less noble $\mathrm{Fe}$ deposits preferentially under most plating conditions. This anomalous codeposition was caused by the suppression of Ni deposition due to the codeposition of Fe.

(2) The anomalous codeposition behavior in Fe-Ni alloy deposition was evidently dependent on the $\mathrm{pH}$ buffer capacity of the solutions. This can be explained in terms of the preferential adsorption of $\mathrm{FeOH}$ on the deposition sites of more noble $\mathrm{Ni}$ due to the extremely smaller dissociation constant of $\mathrm{FeOH}^{+}$than $\mathrm{NiOH}^{+}$in the multi-step reduction process of hydrated iron-group metal ions.

(3) The degree of the preferential deposition of less noble Fe was decreased under the plating conditions that the formation of $\mathrm{FeOH}_{\mathrm{ad}}$ retarded.

(4) The formation of $\mathrm{FeOH}^{+}$in the cathode layer during the anomalous codeposition was confirmed by directly measuring the $\mathrm{pH}$ profiles near the cathode and by measuring the $\mathrm{pH}$ titration curves of the single Fe solution.

\section{REFERENCES}

1) Y. Suganuma, F. Goto and T. Osaka: J. Met. Finish. Soc. Jpn. 34 (1983) 254-259.

2) T. Osaka: Sissikihou wo Riyousita Electronics Koukinou Hakumaku Seihou, (in Japanese, Kousinsya Sougou Kougaku Syuppannsya, Tokyo, 1992) pp 4-6.

3) Y. Mouri: Magnetic Sensor Rikougaku, (in Japanese, Koronasya, Tokyo, 1998) pp 1-3.

4) H. Dahms and I. M. Croll: J. Electrochem. Soc. 112 (1965) 771-778.

5) S. Hessami and C. W. Tobias: J. Electrochem. Soc. 136 (1989) 36113616.

6) J. Horkans: J. Electrochem. Soc. 45 (1981) 128-133.

7) M. Yasuda and N. Koura: J. Met. Finish. Soc. Jpn. 33 (1982) 427-433.

8) E. B. Lehman and A. Riesenkampf: Surface Technology 11 (1980) $349-356$.

9) W. C. Grande and J. B. Talbot: J. Electrochem. Soc. 140 (1993) 669674.

10) K. Y. Sasaki and J. B. Talbot: J. Electrochem. Soc. 142 (1995) 775782.

11) M. Matlosz: J. Electrochem. Soc. 140 (1993) 2272-2279.

12) B. C. Baker and A. C. West: J. Electrochem. Soc. 144 (1997) 164-171.

13) J. Vaes, J. Fransaer and J. P. Celis: J. Electrochem. Soc. 147 (2000) 3718-3724.

14) H. Fukushima, T. Akiyama, J. Lee, M. Yamaguchi and K. Higashi: J. Met. Finish. Soc. Jpn. 33 (1982) 574-578.

15) A. Brenner: Electrodeposition of Alloys, (Vols. 1, 2, Academic Press, New York and London, 1963) pp 221-225.

16) H. Fukushima, T. Akiyama, M. Yano, T. Ishikawa and R. Kammel: ISIJ Int. 33 (1993) 1009-1015.

17) A. J. Bard: CHEMICAL EQUILIBRIUM, (Harper \& Raw Publisher, New York, 1966) pp 196.

18) J. O’M. Bockris and H. Kita: J. Electrochem. Soc. 108 (1961) 676-681.

19) M. Yasuda, I. Ono and S. Haruyama: J. Finish. Soc. Jpn. 41 (1990) 312-318. 